\title{
Oorsprong van die drievoudige struktuur van die Heidelbergse Kategismus
}

\begin{tabular}{|c|c|}
\hline $\begin{array}{l}\text { Authors: } \\
\text { Wim Dreyer } \\
\text { Antionette Jan } \\
\text { van Rensburg }{ }^{1}\end{array}$ & \\
\hline $\begin{array}{l}\text { Affiliations: } \\
{ }^{1} \text { Department } \\
\text { History and } \mathrm{Cr} \\
\text { Faculty of The } \\
\text { University of P } \\
\text { South Africa }\end{array}$ & $\begin{array}{l}\text { f Church } \\
\text { urch Polity, } \\
\text { ology, } \\
\text { retoria, }\end{array}$ \\
\hline $\begin{array}{l}\text { Project leader } \\
\text { Project numb }\end{array}$ & $\begin{array}{l}\text { W.A. Dreyer } \\
\text { er: } 77370920\end{array}$ \\
\hline $\begin{array}{l}\text { Description: } \\
\text { This research } \\
\text { research proje } \\
\text { creeds and Co } \\
\text { directed by } \mathrm{Dr} \\
\text { Department o } \\
\text { History and } \mathrm{Cr} \\
\text { Faculty of The } \\
\text { University of P }\end{array}$ & $\begin{array}{l}\text { s part of the } \\
\text { ct, 'Ecumenical } \\
\text { nfessions', } \\
\text { Wim Dreyer, } \\
\text { f Church } \\
\text { urch Polity, } \\
\text { ology, } \\
\text { retoria. }\end{array}$ \\
\hline $\begin{array}{l}\text { Correspondin } \\
\text { Wim Dreyer, } \\
\text { wim.dreyer@ }\end{array}$ & $\begin{array}{l}\text { guthor: } \\
\text { p.ac.za }\end{array}$ \\
\hline $\begin{array}{l}\text { Dates: } \\
\text { Received: } 02 \mathrm{~F} \\
\text { Accepted: } 21 \\
\text { Published: } 26\end{array}$ & $\begin{array}{l}\text { eb. } 2016 \\
\text { une } 2016 \\
\text { Sept. } 2016\end{array}$ \\
\hline $\begin{array}{l}\text { How to cite th } \\
\text { Dreyer, W. \& V } \\
\text { A., 2016, 'Oor } \\
\text { drievoudige st } \\
\text { Heidelbergse } \\
\text { HTS Teologies } \\
\text { Theological St } \\
\text { a3349. http:// } \\
\text { org/10.4102/ }\end{array}$ & $\begin{array}{l}\text { is article: } \\
\text { an Rensburg, } \\
\text { prong van die } \\
\text { ruktuur van die } \\
\text { 'ategismus', } \\
\text { Studies/ } \\
\text { Idies 72(3), } \\
\text { dx.doi. } \\
\text { ts.v72i3.3349 }\end{array}$ \\
\hline $\begin{array}{l}\text { Copyright: } \\
\text { (C) 2016. The A } \\
\text { Licensee: AOS } \\
\text { is licensed unc } \\
\text { Creative Comr } \\
\text { Attribution Lic }\end{array}$ & $\begin{array}{l}\text { uthors. } \\
\text { S. This work } \\
\text { ler the } \\
\text { nons } \\
\text { ense. }\end{array}$ \\
\hline Read online: & \\
\hline 口:pig & $\begin{array}{l}\text { Scan this QR } \\
\text { code with your } \\
\text { smart phone or } \\
\text { mobile device } \\
\text { to read online. }\end{array}$ \\
\hline
\end{tabular}

\begin{abstract}
The Heidelberg Catechism was one of many catechisms that originated during the 16th-century Reformation. It is also known that the authors of the Heidelberg Catechism made use of existing catechisms. The content of 16th-century catechisms consisted mainly of the Decalogue, the Apostolicum and the Lord's Prayer. The Heidelberg Catechism starts with the famous introduction, dealing with man's only comfort, and in three sections with knowledge of our sin and misery, knowledge of our deliverance, and knowledge of how we should be grateful for our deliverance. This contribution points out that the threefold structure of the Heidelberg Catechism is not unique, but appeared in different ways in different catechisms of prominent 16th-century reformers. It is also argued that the Heidelberg Catechism should be read against Lutheran and Calvinistic backgrounds. Finally, it is shown that the Heidelberg Catechism articulated the basic Christian faith in such a beautiful and poignant manner that it stood the test of time as a catechism and confession.
\end{abstract}

\section{Inleiding}

In die westelike grensgebied van Duitsland het 'n paar streke deur die loop van die Kerkhervorming oorwegend Calvinisties geword, onder andere die Palts met Heidelberg as hoofstad. Tydens die opstel van die Heidelbergse Kategismus is die Palts regeer deur Keurvors Frederik III, vir wie die kennis van God en Sy Woord belangrik was. Frederik III het allerlei verkeerde en uiteenlopende godsdienstige beskouings onder sy mense waargeneem en dit toegeskryf aan die feit dat hulle nie eenvormige onderrig uit ' $n$ goeie kategismus gehad het nie. Daar het groot verdeeldheid in die gebied geheers tussen Lutherane en Calviniste, wat selfs by geleentheid op geweld uitgeloop het. Daarom het hy die inisiatief geneem en opdrag gegee om 'n kategismus op te stel, beide in Duits en in Latyn (vgl. Dreyer 2014).

Die Heidelbergse Kategismus (hierna:HK) was een van vele leerboeke wat tydens die Kerkhervorming ontstaan het. Soos algemeen bekend, is die HK drieledig gestruktureer (kennis van sonde, kennis van verlossing en kennis van dankbaarheid), met die bekende inleiding wat handel oor die mens se enigste troos in lewe en sterwe. Ons enigste troos is dat ons met liggaam en siel aan ons enigste Verlosser en Saligmaker, Jesus Christus, behoort. Hierdie troos berus op die kennis van ons sonde, die kennis van ons verlossing en derdens hoe die mens in dankbaarheid teenoor God kan leef.

In hierdie artikel word die herkoms van die drievoudige struktuur van die HK ondersoek en aangetoon dat dit (1) nie totaal uniek is nie, maar op verskillende maniere in kategismusse van prominente sestiende eeuse kerkhervormers teenwoordig is en (2) voortvloei vanuit die HK se verstaan van 'troos'.

\section{Kategese tydens die Kerkhervorming}

Geloofsonderrig (kategese) het al voor die Kerkhervorming aandag geniet. Gedurende die Middeleeue was dit die taak van priesters om die hoofpunte van die Christelike leer aan die kerkvolk te verduidelik (Schulze 1994:195). Nadat die bieg in 1215 verpligtend geword het, het dit die gewoonte geword om voor die bieg 'n reeks preke oor die Dekaloog en die doodsondes te hou. Die reformatore het by hierdie tradisie aangesluit, behalwe dat hulle die biegpraktyk in sekere gebiede met Bybelse kategese vervang het. Die reformatore het dikwels van materiaal gebruik gemaak wat reeds voor die Kerkhervorming by groepe soos die Waldense en Boheemse Broeders in gebruik was (Weber 1968:132). Die kategismusse was 'n poging tot Skriftuurlike regstelling van die Middeleeuse leerinhoude (Van der Linde 1976:92).

Note: This article is based on research done by A. Janse van Rensburg for the completion of the degree Magister Theologiae, under supervision of Dr W.A. Dreyer, Department of Church History and Church Polity, Faculty of Theology, University of Pretoria. The support of the University of Pretoria and the Johannes a Lasco Institute (Emden, Germany), is hereby acknowledged with gratitude. 
Ook Luther het by die Middeleeuse tradisie aansluiting gevind, toegespits op die jeug. Hy het so vroeg as 1516-1517 'n reeks preke gehou oor die Tien Gebooie en die Onse Vader en daarop gewys dat onderwys vir die jeug gebrekkig is (Schulze 1994:196). In 1520 het hy sy Eine Kurze Form gepubliseer waarin hy aantoon dat deeglike Bybelse kennis noodsaaklik is vir ' $n$ mens se saligheid (Luther 1966:204-229). Kort daarna (1523) het Zwingli in Zürich met kategetiese onderwys begin en het sy Lehrbüchlein verskyn. In 1526 het Oecolampadius in Basel sy Frag und Antwort zum verhören der Kinder opgestel. 'n Jaar later (1527) het Capito se Der Kinderbericht in Straatsburg verskyn (Schulze 1994:196). In 1529 het die Groot Kategismus en Klein Kategismus van Luther verskyn. In 1534 verskyn Bucer se kategismus in Straatsburg, en in dieselfde jaar die kategismus van Leo Judaeus in Zürich. In 1537 het Calvyn sy eerste kategismus vir die kerk in Genève geskryf. Hierdie werk het uit stellings bestaan wat as opsommings gedien het vir die eerste uitgawe van sy Institusie (1536). In 1542 het Calvyn 'n tweede kategismus vir die gebruik van die kerk in Genève opgestel (Van der Linde 1976:97-100). In Zürich het Bullinger sy Hausbuch (1552), Summa christenlicher Religion (1556) en Catechismus (1560) uitgegee. In Emden het Johannes à Lasco ook 'n kategismus opgestel (Schulze 1994:197).

Ursinus het in sy ontwerp en eindredaksie van die Heidelbergse Kategismus (HK) van verskeie kategismusse gebruik gemaak, veral die van Straatsburg (Capito, Bucer en Zell), Zürich (Judaeus, Bullinger), Genève (Calvyn) en Emden (à Lasco) (Engelbrecht 1989:632). Daarnaas is die HK beïnvloed deur Beza se Confessio Brevis, Calvyn se Institutio Christianae Religionis en geskrifte van Melanchthon en Bullinger. So het die Kategismus verteenwoordigend van 'n breë spektrum van reformatoriese teologie geword (Oberholzer 1986:2; Engelbrecht 1943-1944:165).

\section{'Troos' in die Heidelbergse Kategismus}

Karl Barth was oortuig daarvan dat die drieledige struktuur van die HK voortvloei vanuit die eerste vraag en antwoord oor 'troos' (Barth 1964:124). Wat belangriker is, is die boodskap van troos en hoop wat in die HK te vind is (Barth 1964:121). Die kern van die HK handel oor ons troos: 'Wie is die mens wat getroos word en hoe word hierdie troos gegee en waaruit bestaan dit?' (Barth 1964:124).

'Wie is die trooster?' is volgens Karl Barth 'n sentrale vraag in die HK. Die antwoord is dat Jesus Christus ons Trooster is omdat Hy ons plek voor God ingeneem het. Hy kon dit doen omdat Hy die geliefde Seun van God is wat soos ons geword het. Hy los ons ook nie alleen nie. Die Gees en Jesus se bloed speel 'n belangrike rol in die HK (Barth 1964:127). Die persoon wat vertroos word, is die persoon wat verlos is. Christus is die een wat ons verlos (Barth 1964:133).

Die HK is tog ook uniek: Anders as kategismusse wat gegroei het uit óf Calvinistiese of Lutherse tradisies, het dit ontstaan as 'n 'ekumeniese' dokument van onmiddellike belang vir die lewe en werk van die kerk (Barth 1964:22). Die HK handel oor die lewe van die kerk, en kerk gaan oor sonde, verlossing en dankbaarheid. Dit is die evangelie wat ons elke Sondag verkondig en dit is die struktuur van ons prediking en teologie.

Die drie kernpunte van die HK (sonde, verlossing en dankbaarheid) kan by uitstek as ' $n$ samevatting van die reformatoriese leer beskou word en bring op 'n besonderse manier die algemene evangeliese geloof tot uitdrukking (Barth 1964:25). Die HK is nie 'n stuk teorie nie, maar 'n dokument wat gebruik word om die evangelie te verkondig. Dit is as kategismus opgestel, maar het spoedig in verskillende kerke as belydenisskrif en riglyn vir die prediking gefunksioneer, veral in Nederland na die Sinode van Emden (1571).

Daar moet met Barth saamgestem word dat die drieledige struktuur van die HK ten nouste verband hou met reformatoriese verstaan van Christelike troos. 'Troos' kom as herhalende tema deur die $\mathrm{HK}^{1}$ na vore:

Vraag 1: Wat is jou enigste troos in lewe en in sterwe?

Antwoord: Dat ek met liggaam en siel in lewe en in sterwe nie aan myself nie, maar aan my getroue Verlosser, Jesus Christus behoort. Hy het met sy kosbare bloed vir al my sondes ten volle betaal en my uit alle heerskappy van die duiwel verlos. Hy bewaar my op so ' $n$ wyse dat sonder die wil van my hemelse Vader geen haar van my kop kan val nie. Alles moet inderdaad tot my saligheid dien. Daarom verseker Hy my ook deur sy Heilige Gees van die ewige lewe en maak Hy my van harte gewillig en bereid om voortaan vir Hom te lewe.

Vraag 2: Hoeveel dinge moet jy weet om in hierdie troos salig te kan lewe en sterwe?

Antwoord: Drie dinge: Ten eerste, hoe groot my sonde en ellende is; ten tweede, hoe ek van al my sonde en ellende verlos word en ten derde, hoe ek God vir so 'n verlossing dankbaar moet wees.

Vraag 52: Hoe word jy getroos deur die wederkoms van Christus om te oordeel die wat nog lewe en die wat reeds gesterf het?

Antwoord: Dat ek in alle droefheid en vervolging dieselfde Persoon met gespanne verwagting as Regter uit die hemel verwag wat Hom tevore in my plek voor die regbank van God gestel en alle vervloeking van my weggeneem het. Verder: dat Hy al sy en my vyande in die ewige verdoemenis sal werp maar my, saam met al die uitverkorenes, na Hom in die hemelse blydskap en heerlikheid sal neem.

Vraag 53: Wat glo jy van die Heilige Gees?

Antwoord: Eerstens is Hy saam met die Vader en die Seun ware en ewige God. Tweedens is Hy ook aan my gegee sodat Hy my deur ' $n$ ware geloof deel laat kry aan Christus en al sy weldade, my troos en ewig by my bly.

Vraag 57: Watter troos gee die opstanding van die vlees aan jou?

Antwoord: Dat nie alleen my siel na hierdie lewe dadelik tot Christus, sy Hoof, opgeneem sal word nie, maar ook hierdie selfde liggaam van my, deur die krag van Christus opgewek, weer met my siel verenig en aan die heerlike liggaam van Christus gelykvormig sal word.

Vraag 58: Watter troos skep jy uit die artikel van die 'ewige lewe'?

Antwoord: Dat, aangesien ek nou reeds die begin van die ewige vreugde in my hart ervaar, ek na hierdie lewe volkome saligheid

1.Alle Afrikaanse aanhalings uit die Heidelbergse Kategismus is ontleen aan die Diensboek van die Ned. Hervormde Kerk van Afrika, te vind by http://www.nhka. org/index.php/so-glo-ons-11/ref-belydenisskrifte/heidelbergse-kategismus.html 
sal besit - 'n saligheid wat geen oog gesien, geen oor gehoor en in die hart van geen mens opgekom het nie - om God daarin ewig te prys.

Die eerste twee vrae en antwoorde van die HK is die bekendstelling vir die res van die HK se tema en struktuur. Die woord 'troos' is ' $n$ belangrike tema in die HK. Dit word in die eerste twee vrae gebruik as 'n naamwoord, en dan nog vier keer in die res van die HK as 'n werkwoord. In HK Vraag 53 word ons herinner aan HK Vraag 1 wat vertel van die troos wat die Heilige Gees vir ons gee. Die opstanding waarvan ons in HK Vraag 57 lees, is die finale troos (Bierma 2013a:13). Dit gaan nie in die eerste plek oor hoeveel keer die woord troos in die HK gebruik word nie, maar oor hoe dit verbind word aan die drieledige struktuur van die HK. Om te lewe en te sterwe in hierdie troos moet ons (1) ons ellende ken, (2) weet hoe ons verlos kan word en (3) die inhoud van ons dankbaarheid verstaan (Bierma 2013a:15). Die 127 vrae van die Heidelbergse Kategismus wat oorbly, word in hierdie drie dele opgedeel.

\section{Verdere toeligting ten opsigte van die Heidelbergse Kategismus se gebruik van kategismusse}

Die mening is al dikwels uitgespreek dat Ursinus se Kleiner Kategismus (1561-1562) en tot 'n mindere mate sy Groter Kategismus (1562) as basis vir die drieledige struktuur van die HK gedien het (Lang 1907). Dat die twee bronne wel die struktuur beïnvloed het, is nie te betwyfel nie. Die afhanklikheid van hierdie twee bronne ten opsigte van die struktuur is reeds duidelik in die openingswoorde van HK Vraag 1, wat duidelik taalkundige ooreenkomste toon met die Kleiner- en Groter Kategismus (soos aangehaal in Bierma 2013a):

\section{Kleiner Kategismus 1}

SC $1 \mathrm{Q}$. What is the comfort by which your heart is sustained in death as well as in life?

That God has truly pardoned all my sins because of Christ and has given me eternal life, in which I may glorify him forever. (p. 15; vgl. Lang 1907:200-201)

Groter Kategismus 1

LC1 Q. What firm comfort do you have in life and in death?

That I was created by God in his image for eternal life, and after I willingly lost this in Adam, out of his infinite and gracious mercy God received me into his convenant of grace, so that because of the obedience and death of his Son sent in the flesh, he might give me as a believer righteousness and eternal life. It is also that he sealed his covenant in my heart by his Spirit, who renews me in the image of God and cries out in me, 'Abba Father', by his Word, and by the visible signs of this covenant. (p. 15)

Alhoewel HK Vraag 1 die taal volg van die Kleiner- en Groter Kategismus van Ursinus, verskil die antwoord van HK Vraag 1 tog daarmee. Die Kleiner Kategismus kom ook nie ooreen met die ander vrae (HK52, HK53, HK57, HK58) waar daar van troos gepraat word nie (Bierma 2013a:15).

In die Kleiner Kategismus kom troos net drie keer voor in Vraag 1 en dan ook in Vraag 51 en 52. In die Groter Kategismus kom troos ses keer voor - Vrae 1, 103, 110 en 131. Hierdie vrae het ooreenkomste met HK 1, 52, 53 en 58. Die ander twee plekke waar die woord troos voorkom, is in Antwoord 64 wat handel oor die ampte van Christus en Antwoord 141 wat handel oor regverdiging. In teenstelling met die HK vorm troos nie die basiese struktuur van Ursinus se Groter Kategismus nie (Bierma 2013a:16).

Die voor die hand liggende teks wat as bron vir HK Vraag 2 sou kon dien is die derde vraag en antwoord van Ursinus se Kleiner Kategismus (sien Bierma 2013a):

\section{Q. What does God's word teach?}

A. First, it shows us our misery, second, how we are delivered from it, and third, what gratitude ought to be shown to God for this deliverance. (p. 22)

Daar kan egter nie met Ursinus se Kategismus volstaan word nie, want daar is ook verskeie ander bronne wat die drieledige struktuur van die HK kon beïnvloed het. Die oudste van hierdie tekste is deur August Lang voorgestel, naamlik 'n vroeë kategetiese werk van Martin Luther met die titel Eine kurze Form der zehn Gebote ${ }^{2}$ (Lang 1907:LXXX). Luther maak in hierdie werk gebruik van 'n mediese metafoor wat ' $n$ driedelige struktuur voorstel:

Three things a person must know in order to be saved. First, he must know what to do and what to leave undone. Second, when he realises that he cannot measure up to what he should do or leave undone, he needs to know where to go and find the strength he requires. Third, he must know how to seek and obtain that strength. It is just like a sick person who first has to determine the nature of his sickness, then find out what to do or leave undone. After that, he has to know where to get the medicine which will help him do or leave undone what is right for a healthy person. Third, he has to desire to search for this medicine and to obtain it or have it brought to him. Thus the commandments teach man to recognize his sickness ... and so he will recognise himself to be a sinful and wicked person. The Creed holds before him and teaches him where to find the medicine, the grace, that will help him to keep the commandments; and the Creed points him to God and his mercy, given and made plain to him in Christ. Third, the Lord's Prayer teaches him how to desire, obtain, and have this medicine brought to him, namely, with proper, humble, comforting prayer ... in these three are the essentials of the entire Bible.

Die struktuur laat ' $n$ mens baie aan die HK dink, aangesien die HK ook die wet in deel een en die belydenis in deel twee behandel. Volgens Lang het Ursinus Luther se siekte en medisyne vervang met ellende en verlossing (Lang 1907:LXXX, CI).

'n Verdere moontlike bronteks is in die 19de eeu geïdentifiseer deur Maurits Gooszen, naamlik Phillip Melanchthon se Loci Communes Theologici van 1521 (Goozsen 1890:75). Volgens Gooszen neem die Loci Communes Theologici sy vorm aan deur drie bewegings, naamlik: van sonde en die wet tot genade en die evangelie na bekering en die sakramente. Dis 'n vorm wat Melanchthon gevolg het wat ooreenkom met die buitelyne van Romeine 10 (Wengert 1996:131)

2.Luther, M., 1520, 'Eine kurze Form der zehn Gebote, eine kurze Form des Glaubens, eine kurze Form des Vaterunsers', in D. Martin Luthers Werke: Kritische Gesammtausgabe, vol. 7 . 
In die 20ste eeu het Johann Reu op 'n derde moontlike bron afgekom vir die struktuur van die HK, in Engels bekend as A brief orderly summary of the right true doctrine of our holy Christian faith (Bierma 2013a:23). Die dokument is van Lutherse oorsprong, maar die outeur is onbekend. Dit is in 1547 in Regensburg gepubliseer en het gedien as 'n samevatting van die Lutherse leer. Wat interessant is oor hierdie dokument, is dat die afdelings georganiseer is onder die drie leerstellige opskrifte (1) wet en sonde, (2) evangelie en geloof en (3) goeie werke. In die verduideliking van elke afdeling vind mens die woorde ellende, verlossing en dankbaarheid (Reu 1976:198-199). Die opsomming sluit af met 'n vlugtige Christelike belydenis vir jong kinders en eenvoudige mense wat in drie dele verdeel is (eie vertaling van Reu 1976):

Eerste: Ek bely dat ek ' $n$ arm sondige wese is.

Tweede: Ek bely en ek glo dat ons Here Jesus Christus vir my vergifnis vir my sonde verkry het en die ewige lewe gee.

Derde: Ek bely dat vir sulke groot genade en goedheid ek waarlik dankbaar moet wees teenoor God. (p. 734; vgl. Bierma 2013a:23)

Walter Hollweg het ' $n$ vierde moontlike bron op die tafel geplaas. Hy het 'n parallel raakgesien tussen die HK en Theodore Beza se verduideliking van die drievoudige werk van die Heilige Gees in sy Altera Brevis Fidei. Hy het bevind dat die werking van die Gees betrekking het op (1) sonde, (2) redding deur die evangelie en (3) verlossing. Volgens Hollweg het Beza naby bande gehad met die Heidelbergse gemeenskap en sy kleiner belydenis is in Duits vertaal en in 1562 in Duitsland gepubliseer (Hollweg 1961:88-94).

Die mediese metafoor wat Luther gebruik om die verband tussen wet en evangelie te verduidelik word herhaal in die kerkorde van die Palts onder die instruksies oor prediking (Latzel 2004:97). Ten spyte van die bogenoemde, maak Luther se skema geen melding van dankbaarheid of goeie werke nie. Die wortels van die verband tussen dankbaarheid en goeie werke wat ons in HK Vraag $86 \mathrm{kry}$, is eerder te vinde in Johannes Brenz se Kategismus van 1535 (sien Bierma 2013b):

Vraag: Waarom moet ons goeie werke doen?

Antwoord: Nie omdat ons vir ons sonde betaal en die ewige lewe verkry deur goeie werke nie, want Christus alleen het vir ons sonde betaal en die ewige lewe verkry, maar eerder omdat ons moet getuig van ons geloof met goeie werke en dankbaar wees teenoor God vir sy goeie werke. (pp. 31-39)

Brenz se Kategismus poog om vier temas te behandel (vgl. Bruggink 1963): (1) Apostoliese Geloofsbelydenis, (2) Onse Vader, (3) Tien gebooie, (4) Sakramente.

Hierdie vier temas kom ook in die HK voor. Dit vorm die grootste deel van die inhoud van die HK. Maar wat interessant is, is dat hulle in die HK nie afsonderlik as temas wat niks met mekaar te doen het aan die orde gestel word nie. Hulle word eerder in mekaar vervleg in 'n sinvolle struktuur. Die grondstruktuur van die Heidelbergse Kategismus is gevolglik drieledig: Die eerste deel word die mens se sonde en ellende genoem, die tweede deel verlossing en vryheid en die laaste dankbaarheid en gehoorsaamheid (Bruggink 1963) wat alles aan mekaar gebind word deur die sentrale gedagte van troos.

\section{Eie aksente in die Heidelbergse Kategismus}

Die eie aksent van die HK is dat dit met die vraag na troos begin en dit op ' $n$ besonder sistematiese en koherente wyse verder uitwerk. Daarvoor is daar geen analogie by Luther of by Calvyn nie (Schulze 1994:205). Die uniekheid van die $\mathrm{HK}$ is te vind in die wyse waarop daar met die materiaal omgegaan word.

Die HK begin met die vraag na die troos, soos in Ursinus se Groter- en Kleiner Kategismus. Die Maior plaas die troos binne die kader van die verbond en in die Minor is die verbond weggelaat, maar ons vind dit in die eerste vraag (Schulze 1994):

Vraag: Wat is jou troos, waardeur jou hart hom in lewe en sterwe staande hou?

Antwoord: Dat God my al my sonde om Christus wil vergeef het en my die ewige lewe geskenk het, waarin ek Hom vir ewig sal verheerlik. (p. 205)

Die antwoord wys teosentries op God se heilshandeling in Christus. In die HK is die troosgedagte nog dieper in ' $n$ formulering uitgewerk. Hierdie formulering is Christosentries 'dat ek aan my getroue Verlosser behoort' (Schulze 1994:205). Daarna volg die trinitariese vermelding van God se genadewerk vir en aan ons, met die volgorde: Christus, Vader, die Heilige Gees. As ons mooi na die formulering van die HK kyk, dan vervaag die stempel van Ursinus. Die troosgedagte is daar, maar anders as in Ursinus se Maior en Minor.

Ook Joachim Mörlin se 1547 Kategismus begin met 'n soortgelyke vraag: 'Was ist dein Trost für aller Welt auf Erden?' (Weber 1968:134). Dit is wel twyfelagtig of Mörlin se kategismus in Heidelberg bekend was. Dit is ook aangetoon dat die HK se sistematiese en parallelle opbou van die vrae oor die doop en nagmaal van Boquinus afkomstig kon gewees het (Steenkamp 1989:613). Laasgenoemde het in 1561 in Heidelberg ' $n$ geskrif opgestel met die titel Exegesis divinae et humanae koinonias, waarin hy die doop en nagmaal teologies begrond het (Schulze 1994:206).

'n Ander belangrike aksent in die HK is kennis. Kennis is die Leitmotiv wat die struktuur van die kategismus bepaal. Die HK hoort struktureel tot dieselfde tipe as die Geneefse Kategismus. Die geheel word vanuit die vraag na troos ontwikkel. Troos is nie bloot ' $n$ gevoelsaak nie, maar is ' $n$ wete, dit is op kennis gegrond - naamlik kennis van die mens se sonde, verlossing en dankbaarheid (Schulze 1994:208). Die gedagte dat heiligmaking in die gestalte van dankbaarheid na vore kom, word reeds in die Apologie van die Augsburg Konfessie genoem: 'Darum sollen gute Werke dem Glauben folgen als Danksagung gegen Gott' (Neuser 1979:188).

Melanchthon noem die dankbaarheid nie net in die Apologie nie, maar ook in sy Unterricht der Visitatoren (Weber 1968:135). Ursinus, as student van Melanchthon, moes op hoogte wees 
van hierdie gedagtes van sy leermeester. Nog ' $n$ voorbeeld is die Regensburg dokument wat in 1544 verskyn het en ook die driedelige ellende, verlossing en dankbaarheid noem (Weber 1968:135; Neuser 1979:188). Dit is in 1558 in Heidelberg herdruk en was aan die kommissie wat die HK geskryf het bekend. Dit was nie in die vorm van vraag en antwoord nie, en die Regensburg dokument se uitbreiding van die dankbaarheidgedagte was karig. Daarom meen navorsers soos Weber (1968:136) en Neuser (1979:189) dat die kommissie nie werklik 'n voorbeeld gehad het waar sonde, verlossing en dankbaarheid as driedelige indeling die bou van 'n werk kon bepaal nie. Juis die gebruik van hierdie begrippe om die HK in drie dele te verdeel, was dus 'n geniale greep van die kommissie.

Die struktuur van die HK is 'n pragwerk en die resultaat van deeglike navorsing en spanwerk (Schulze 1994:208). Naatloos word die drie hoofsomme van die leer in die drieledige struktuur van die Heidelbergse Kategismus ingeweef: in deel een die mens se sonde en verlorenheid; in deel twee die mens se verlossing en in deel drie die gehoorsaamheid aan die wet en gebed as gestaltes van dankbaarheid. Geen wonder dat die HK in baie lande inslag gevind het en ander kategismusse verdring het nie. Dit is gevestig as 'n geliefde leerboek en ' $n$ suiwere samevatting van die Bybelse waarheid (Schulze 1994:208).

\section{Slot}

Om te besluit dat een spesifieke teks die drieledige struktuur van die Heidelbergse Kategismus bepaal het, is onmoontlik. Daar is ook verder aangetoon dat troos ' $n$ kerngedagte in die $\mathrm{HK}$ is, en dat die bepaalde verstaan van troos deur die opstellers die struktuur van die HK bepaal het.

Die drieledige struktuur van die HK maak dit 'n unieke dokument, nie omdat dit net in die HK voorkom nie maar omdat dit die Christelike geloof op ' $\mathrm{n}$ besonderse wyse verwoord en struktureer. Die HK begin met die mooi opening dat ons as mense aan God behoort. Die basiese struktuur van die HK maak dit 'n aantreklike en tydlose dokument. Soos bo genoem, is die sentrale tema van die Kategismus 'troos' (Smit 2014:53). Die tema van troos bepaal die hele struktuur en opbou van die HK. Die drie hoofdele van ellende, verlossing en dankbaarheid vorm integraal deel van ons troos (Smit 2014:55). Die implikasie is dus dat die eerste deel oor die kennis van ons ellende eweneens deel van ons troos is en slegs moontlik is deur die verlossing van Jesus. Die derde deel oor dankbaarheid is ook deel van hierdie troos deurdat Jesus Christus ons self deur sy Woord en Gees van harte dankbaar maak (Smit 2014:55). Die selfkennis oor ons ellende is ook die vrug van dankbaarheid en alles vorm deel van hierdie troos (Smit 2014:55).

Die HK dinknie in terme van drie fases of agtereenvolgende stappe van geestelike ervaring nie, maar oor een werklikheid. Die drie woorde verwys nie na 'n kronologiese orde nie, maar na 'n logiese orde (Berkhof 1963:96). Die tema van troos vorm daarom die deurlopende motief in die HK. Wat die rangskikking betref, word die wet nie vooraf behandel en gesien as tugmeester nie, maar as deel van die dankbare lewe waartoe die Heilige Gees gelowiges roep (Smit 2014:56). Ons ellende is nie dat ons individuele gebooie oortree en spesifieke sondes begaan nie, maar dat ons vervreem leef van die liefde waartoe ons bedoel is en wat deur Jesus weer aan ons geskenk word. Deur die vertroue op die beloftes wat in die geloofsbelydenis aan ons gegee word en deur die genademiddele van die Woord en sakrament wat die Heilige Gees gebruik, kry ons deel aan hierdie troos (Smit 2014:56). So word al die dele geïntegreer in een groot geheel wat alles dien tot ontvouing van die troos wat reeds in die eerste antwoord gegee is (Smit 2014:56).

\section{Erkenning Mededingende belange}

Die outeurs verklaar dat hulle geen finansiële of persoonlike verbintenis het met enige party wat hulle nadelig kon beïnvloed het in die skryf van hierdie artikel nie.

\section{Outeursbydrae}

A.v.R. was verantwoordelik vir die teksbydrae wat gelewer is en W.D. was verantwoordelik vir die supervisie daarvan.

\section{Literatuurverwysings}

Barth, K., 1964, Learning Jesus Christ through the Heidelberg Catechism, transl. S.C. Guthrie, Eerdmans, Grand Rapids, MI.

Berkhof, H., 1963, 'The Catechism as an expression of our faith', in B. Thompson, H. Berkhof, E. Schweizer \& H.G. Hageman (eds.), Essays on the Heidelberg Catechism, pp. 93-122. United Church Press, Philadelphia, PA.

Bierma, L.D., 2005, An introduction to the Heidelberg Catechism: Sources, history and theology, Baker Academic, Grand Rapids, MI.

Bierma, L.D., 2013a, The theology of the Heidelberg Catechism: A Reformation synthesis, Westminster John Knox Press, Louisville, KY.

Bierma, L.D., 2013b, 'The origins of the threefold structure of the Heidelberg Catechism: Another look', in K. Apperloo-Boersma \& H.J. Selderhuis (eds.), Power of faith: 450 years Heidelberg Catechism, pp. 31-40, Vandenhoeck \& Ruprecht, Göttingen.

Bruggink, D.J., 1963, Guilt, grace, and gratitude: A commentary on the Heidelberg Catechism, commemorating its 400th anniversary, Half Moon Press, New York.

Dreyer, W.A., 2014, 'The Heidelberg Catechism: A 16th century quest for unity', HTS Teologiese Studies/ Theological Studies 70(1), Art. \#2092, 5 pages. http://dx.doi. org/10.4102/hts.v70i1.2092

Engelbrecht, B.J., 1989, "n Vergelyking tussen die teologie van die Nederlandse Geloofsbelydenis en die Heidelbergse Kategismus', HTS 45, 626-644.

Engelbrecht, S.P., 1943-1944, 'Die Heidelbergse Kategismus as kerklikle simbool', HTS Teologiese Studies 1, 160-173.

Gooszen, M., 1890, De Heidelbergsche Catechismus: Textus Receptus met toelichtende teksten, Brill, Leiden.

Hollweg, W., 1961, Neue Untersuchungen zur Geschichte und Lehre des Heidelberger Katechismus, Neukirchener Verlag, Neukirchen.

Klooster, F.H., 1965, 'The Heidelberg Catechism An ecumenical creed?', Bulletin of the Evangelical Theological Society 8(1), 23-33, viewed 23 November 2014, from http://www.biblicalstudies.org.uk/pdf/beys/vol08/8-1_klooster.pdf

Lang, A. (ed.), 1907, Der Heidelberger Katechismus und vier verwandte Katechismen, Deichert, Leipzig.

Latzel, T., 2004, Theologische Grundzüge des Heidelberger Katechismus: eine fundamentaltheologische Untersuchung seines Ansatzes zur Glaubenskommunikation, Elewert, Mamburg.

Luther, M., 1966, D Martin Luthers Werke: Kritische Gesamtausgabe, Bd 7, Bohlaus, Weimar.

Fey, H.E., 1963, 'More than a memorial', in The Christian Century LXXX(7), 198.

Neuser, W., 1979, 'Die Väter des Heidelberger Katechismus', Theologische Zeitschrift 35, 177-199. 
Oberholzer, J.P., 1986, Die Heidelbergse Kategismus in vier teksuitgawes, met inleiding en teksvergelyking, Kital, Pretoria.

Reu, J.M., 1976, Quellen zur Geschichte des kirchlichen Unterrichts in der evangelischen Kirche Deutschlands zwischen 1530 und 1600, Reprint of the edition Gütersloh 1904-1935, Hildesheim et al., vol. 1-9.

Schulze, L.F., 1994, 'Die teologiese wortels en struktuur van die Heidelbergse Kategismus: 'n Oorsig', HTS 50(1\&2), 194-210.

Smit, D., 2014, 'Oor die inhoud en boodskap van die Heidelbergse Kategismus', Acto Theologica 2014 suppl. 20, 50-73.

Steenkamp, J.J., 1989, 'Ursinus, die opsteller van die Heidelbergse Kategismus, Olevianus en die Heidelbergse teologie', HTS Teologiese Studies/Theological Studies, 45, 611-625.
Van der Linde, S., 1976, De Heidelbergse Catechismus in het kader van het Gereformeerd Protestantisme: Opgang en voortgang der Reformatie, Ton Bolland, Amsterdam.

Weber, O., 1968, 'Analytische Theologie - Zum geschichtliche Standort des Heidelberger Katechismus: Die Treue Gottes in der Geschichte der Kirche', Gesammelte Aufsatze 2:131-146, in $\mathrm{H}$. Erhart et al. (Hrsg.), Beitrage zur Geschichte und Lehre der reformierten Kirche, Bd 29, Neukirchener Verlag, Geschichte

Wengert, T.J., 1996, 'Philip Melanchthon's 1522 Annotations on Romans and the Lutheran Origins of Rhetorical Criticism', in R.A. Muller \& J.L. Thompson (eds.), Biblical interpretation in the era of the Reformation: Essays presented to David C. Steinmetz in honor of his sixtieth birthday, pp. 118-140, Eerdmans, Grand Rapids, MI. 